\title{
Comparative Alterations in the Compositional Profile of Selected Root and Vegetable Peels Subjected to Three Pretreatments for Enhanced Saccharification
}

\author{
Mithra. M. G, Padmaja. G \\ Division of Crop Utilization, ICAR- Central Tuber Crops Research Institute, Kerala, India
}

\begin{abstract}
Lignocellulosic feedstocks have gained worldwide interest as alternative biofuel source in the context of squeezing petroleum resources, enhanced environmental pollution from greenhouse gases and resulting climate change. The potential of agricultural processing residues such as root and vegetable peels (beet root, greater yam, pumpkin and vegetable banana) for bioethanol production was investigated through an understanding of their compositional profile and efficacy of three pretreatments in altering their composition and reducing biomass recalcitrance. Starch was the major polysaccharide in the residues (range: 25-37\%), followed by cellulose (18-22\%) and hemicellulose (15-20\%). While dilute sulfuric acid (DSA; $\left.121^{\circ} \mathrm{C} ; 0.102 \mathrm{MPa}\right)$ hydrolyzed starch and hemicellulose to a high extent, steam pretreatment of moist residues $(40 \%$ and $50 \%$ MC) at $100{ }^{\circ} \mathrm{C}$ also facilitated hemicellulose and starch solubilization. On the contrary, lime pretreatment retained most of the cellulose, hemicellulose and starch in the pretreated residues. Delignification was the highest (28-37\%) in steam pretreated residues, with minimal effect in DSA and lime pretreatments, necessitating lignin binding surfactants during saccharification in the latter. Reducing sugar content in pretreated liquors and Pretreatment Efficiency (\%) were the highest (40-45 $\mathrm{g} \mathrm{L}^{-1}$ and $57-64 \%$ respectively) in the DSA pretreatment. The study showed that as the pretreated liquor DSA and steam pretreatment was rich in fermentable sugars, whole slurry saccharification would be beneficial for maximizing the bioethanol yield.
\end{abstract}

Keywords - Composition, peels, root and vegetables, pretreatment, steam, lime, DSA

\section{INTRODUCTION}

The increasing demand for transportation fuel especially from the oil-dependent nations of the world, due to enhanced population growth and rapid industrialization has necessitated the look out for alternative fuel sources which are relatively cheap and environment friendly. www.ijeab.com
Excessive burning of coal and fuel has been associated with the global warming and climate change which are going to be the threatening issues of the near future [1]. Bioethanol is regarded as the best alternative to petroleum-based fuel, due to its high $\mathrm{O}_{2}$ content (35\%) and ability to reduce the emission of toxic gases which contribute to greenhouse effect [2,3]. Lignocellulosic biomass (LCBs) is identified as the best raw material for bioethanol production due to several factors such as abundant and cheap global availability, non-food resource and effective waste valorization potential [4,5]. Although a major part of LCBs is constituted by agricultural residues and woody biomass or dedicated crops such as switchgrass or coastal Bermuda grass $[4,6]$, there is also in increasing contribution from processing wastes resulting from enhanced industrial activities. Being waste byproducts, their effective valorization for bioethanol production could also help control pollution and health hazards from inadequate waste disposal.

Banana is an important fruit crop grown in the tropics and sub-tropics and currently India is the world's leading producer with a production of 27.58 million tomes accounting for $25 \%$ of the world [7]. Three common species of banana grown in the world are Musa cavendishii, $M$.paradisiaca and $M$. sapientum. Banana peel is a major agro-waste of most developed and developing nations which is currently utilized as animal feed source or for extraction of fiber, ethanol and pectins $[8,9]$. Cooking (vegetable) banana falls under ABB group and very little research has been conducted on the utilization of its peel, although extensive studies have been conducted on the byproduct utilization of plantain and fruit (ripe) banana peels $[10,11,12]$. Hence, the potential of cooking banana peels as a source for bioethanol production was investigated. Besides, two other wastes generated from commonly consumed vegetables such as beet root (Beta vulgaris) and pumpkin (Cucurbita moschata) were also studied for their efficiency as a $2 \mathrm{G}$ ethanol sources. Beet root also known 
as garden beet is extensively cultivated as an anti-oxidant rich vegetable in tropical countries and is also utilized for the extraction of betalains and natural colours [13,14].

The residue after extraction of pigments is a rich source of cellulose, hemicellulose and starch and hence could be a potential candidate for bioethanol production. Cucurbita moschata is cultivated extensively in the world with higher production yield and the pulp is used as vegetable, in soups, juices, puddings, breads etc. [15]. Thick peels comprising approximately $10-15 \%$ of fresh weight are thrown off and scanty literature is available in its utilization [15]. Although several studies have been conducted on the value addition of the pulp and seeds of C. moschata [16], very little is known about the potential of the peels which is a biowaste discarded during processing. Greater yam (water yam; Dioscorea alata) is another root crop species which is extensively cultivated in India and Africa for its starchy tubers. However, there is lot of processing waste due to the irregular morphology of the roots and more than $20 \%$ of the fresh weight is accounted towards peeling waste. Except for a few studies, the potential of yam peel as a bioethanol raw material remains largely untapped [17,18].The objective of the present study was to investigate the potential of peels from beet root, greater yam, pumpkin and vegetable banana for bioethanol production by designing appropriate pretreatment strategies which could help enhance the fermentable sugar yield from them.

Although bioethanol production from lignocellulosic biomass has long been recognized as a good option due to the cheap and abundant availability of the feedstock, its potential largely depends on the cost-effective processing by successfully overcoming the technological barriers. Biomass recalcitrance is the primary obstacle resulting from the highly crystalline nature of cellulose and its poor accessibility to cellulases due to shielding by ligninhemicellulose matrix and has to be effectively tackled through appropriate pretreatment strategies[19]. Pretreatment cost has been identified as the second major contributor to ethanol production cost, first being raw material cost (including enzymes). Hence, research efforts have been intensified in the past few decades to develop cost-effective technologies that support the downstream processing operations with low enzyme dosages and shorter processing time. Variations in the physicochemical characteristics of different lignocellulosic materials necessitate suitable pretreatment technologies to be developed for each of them [20]. Starch, being a major component of the selected biomasses, their pretreatment approaches and resulting compositional alterations may also be different from conventional LCBs.

Dilute sulfuric acid (DSA) has been widely used for the deconstruction of cellulose in agricultural residues, www.ijeab.com woody and herbaceous crops [3,20, 21,22] found that acid pretreatment causes disruption of covalent and hydrogen bonds as well as Vanderwaals forces which hold the biomass components, leading to solubilization of hemicellulose and reduction in cellulose crystallinity. Nevertheless, acid pretreatment has certain disadvantages such as the need for corrosion-resistant reactors, less efficiency of lignin removal and formation of inhibitors such as furfural, 5-hydroxymethyl furfural and acetic acid [23]. In order to overcome such problems, lime (calcium hydroxide) pretreatment has been attempted for several lignocellulosic feedstocks [24,25,26]. Being a cheap chemical that could be safely handled and recovered easily coupled with the low operational temperatures, lime pretreatment has currently regained interest. Removal of acetyl and uronic acid as well as ester linkages by alkali enhances cellulose digestibility and lignin solubilization [23, 27]. Besides, lignocelluloses are swollen in presence of alkali, which increases the accessibility of cellulose to cellulases [26].

We had reported earlier on the compositional variations in the peels from root crops such as sweet potato, elephant foot yam and tannia as well as from the vegetable, ash gourd and the changes they undergo during pretreatment techniques such as steam, dilute sulfuric acid and lime [28, 29]. The objective of the present study was to compare the effects of three pretreatment technologies for the starch-rich residues (lignocellulo-starch biomass) such as peels from beet root, greater yam, pumpkin and vegetable banana, on the compositional alterations brought about so that the most appropriate pretreatment and saccharification process for bioethanol production could be evolved.

\section{MATERIALS AND METHODS}

\subsection{Raw materials and enzymes}

Peels were collected by manual peeling from selected biomass such as beet root, pumpkin (yellow variety), vegetable (cooking) banana (ABB) and greater yam. These were immediately washed in running tap water to remove adhering sand and mud, drained and sun-dried for $36-48 \mathrm{~h}$ to moisture content $<10 \%$. The dry residues were powdered in a hammer mill (particles size: $c a .2-3 \mathrm{~mm}$ ) and used without screening for studies.

The enzymes used in the study for the precise quantification of starch included Spezyme ${ }^{\circledR}$ Xtra and Stargen $^{\mathrm{TM}}$ 002, supplied free of cost by M/S Genecor International Inc., USA (presently M/S Danisco US Inc., USA). As per the manufacturer's guide, Spezyme contained a thermostable $\alpha$ - amylase (E.C.3.2.1.1) with 14000 units of activity (1.0 AAU = amount of enzyme required to hydrolyze $10.0 \mathrm{mg} \mathrm{starch} / \mathrm{min}$ under the assay conditions) and Stargen contained amylase and

Page | 1733 
glucoamylase (E.C.3.2.1.3) which synergistically hydrolyzed granular starch to glucose and had an activity of 570 Glucoamylase units ( 1 unit = amount of enzyme liberating $1.0 \mathrm{~g}$ glucose/h from soluble starch under the conditions of assay [30].

\subsection{Pretreatments}

Three types of pretreatment strategies were adopted such as simple steam $\left(100{ }^{\circ} \mathrm{C}\right)$, dilute sulfuric acid $\left(121^{\circ} \mathrm{C}\right)$ and lime (calcium hydroxide) at $121^{\circ} \mathrm{C}, 50{ }^{\circ} \mathrm{C}$ and room temperature $\left(30 \pm 1{ }^{\circ} \mathrm{C}\right)$. In the case of simple steam treatment (herein after referred to as ST), the biomass powders were moistened to $40 \%$ and $50 \%$ moisture content respectively and exposed to steam for $30 \mathrm{~min}, 45$ min and $60 \mathrm{~min}$ in a vegetable steamer (M/S TTK Prestige India Ltd, India) [28] . Samples after pretreatment were suspended in distilled water $(3: 20 \mathrm{w} / \mathrm{v})$ and the soluble fraction was separated from the water insoluble solids (WIS) by centrifugation at $8000 \mathrm{rpm}$ for 30 min. Part of the WIS was lyophilized for ultrastructural studies while the remaining part was dried, powdered and used for the compositional studies.

In the second experiment, biomass samples were treated with dilute sulfuric acid (DSA; $0.5 \% \mathrm{v} / \mathrm{v})$ in a pressure cooker (M/S TTK Prestige India Ltd.) for $30 \mathrm{~min}$ and 60 min at $121^{\circ} \mathrm{C}$ and $0.102 \mathrm{MPa}$ pressure (time after pressure build up). Samples after pretreatment were adjusted to $\mathrm{pH}$ 6.0 using $10 \mathrm{~N}$ sodium hydroxide and then separated to soluble and insoluble fractions, as described earlier (and subjected to studies).

In the third experiment, the biomass residues were subjected to three types of lime pretreatment $(0.1 \mathrm{~g}$ calcium hydroxide per gram dry biomass), such as high temperature $\left(121{ }^{\circ} \mathrm{C} ; 0.102 \mathrm{MPa}\right.$ for $30 \mathrm{~min}$ and $60 \mathrm{~min}$ ) low temperature $\left(50{ }^{\circ} \mathrm{C}\right.$ for $6 \mathrm{~h}$ and $\left.24 \mathrm{~h}\right)$ and room temperature $\left(30 \pm 1^{\circ} \mathrm{C}\right.$ for $24 \mathrm{~h}$ and $\left.48 \mathrm{~h}\right)$. After each sampling period, the biomass slurry was adjusted to $\mathrm{pH}$ 6.0 using concentrated Hydrochloric acid and the soluble and insoluble fractions were separated and subjected to analysis as described earlier.

\subsection{Compositional studies}

\subsubsection{Polysaccharides and lignin}

The native and pretreated biomass samples were subjected to compositional analyses as per the methods described earlier [28]. Starch content was determined by enzymatic assay using Spezyme and Stargen by the standardized method [31]. Biomass $(2.0 \% \mathrm{w} / \mathrm{v})$ was digested sequentially with Spezyme $\left(\mathrm{pH} 5.5 ; 90{ }^{\circ} \mathrm{C} ; 0.5\right.$ $\mathrm{ml}$ ) for $30 \mathrm{~min}$. and Stargen ( $\mathrm{pH} 4.5 ; 40{ }^{\circ} \mathrm{C}$; $0.5 \mathrm{ml}$ ) for 24 h. Sodium azide $(0.25 \% \mathrm{w} / \mathrm{v})$ was added to prevent microbial contamination and the released reducing sugars were quantified by the titrimetric method of [32] using potassium ferricyanide reagent. The interference from hemicellulose and cellulose during acid hydrolysis could www.ijeab.com be avoided in the enzyme method. Enzyme and substrate blanks were kept to eliminate the interference from reducing sugars already present in the enzyme and original biomass respectively. Starch content was calculated using the conversion factor, 0.9 and in the case of pretreated biomass, the content was worked back to the original dry biomass based on the dry solids recovery after pretreatment.

Neutral and acid detergent fiber were determined using the original method of Goering and Vansoest [33] with modifications incorporating amylolytic enzymes to avoid the interference from starch. The biomass slurry after treatment with neutral detergent solution in presence of sodium sulfite was digested with Spezyme and Stargen as described earlier. The contents after $24 \mathrm{~h}$ digestion with Stargen were filtered and residue washed with acetone and dried to quantify the NDF. The ADF content was determined in the NDF fraction by the method of Goering and Vansoest [33] and the values were worked back to the original dry biomass.

Hemicellulose content in the native and pretreated biomass was calculated as the difference between NDF and ADF. Cellulose was quantified as per the method of Updegroff [34] using acetic-nitric reagent with the difference that the ADF fraction was used, which helped to eliminate the interference from starch. Ash content in the native and pretreated biomass was estimated by the AOAC method [35]) by incinerating in a muffle furnace at $550{ }^{\circ} \mathrm{C}$ for $8 \mathrm{~h}$. In order to avoid the overestimation of lignin due to the bound proteins, the protein content in ADF was determined by the Kjeldahl method [35] and subtracted from ADF to get the true ADF (TADF). Lignin content was then computed using the equation:

Lignin $(\%)=$ True ADF $(\%)-[($ cellulose + ash $) \%$

\subsubsection{Sugars and Pretreatment Efficiency}

Total and reducing sugars in the original untreated and pretreated biomass were assayed in the $80 \%$ ethanol extract by the titrimetric method [32]. The reducing sugars in the pretreated liquors were also quantified by the same method. Pretreatment efficiency (\%) was worked out from the total reducing sugars in the pretreated liquors and pretreated residue (value obtained from the substrate blank readings of starch assay) after nullifying the RS originally present in the untreated biomass using the following equation:

$\mathrm{PE}(\%)=[(\mathrm{RSpt}+\mathrm{RSr})-\mathrm{Rsob}] \times 100$

$[\mathrm{C}+\mathrm{HC}+\mathrm{S}+\mathrm{TS}$ in original biomass $(\% \mathrm{dwb})$

where RSpt $=\mathrm{RS}$ released from the biomass due to pretreatment (expressed as \% of the original biomass);

Page | 1734 
$\mathrm{RSr}=\mathrm{RS}$ held back in the pretreated residue (expressed as $\%$ of the original biomass); RSob $=\mathrm{RS}(\%)$ originally present in the biomass; $\mathrm{C}$ : cellulose; $\mathrm{HC}$ : hemicellulose; $\mathrm{S}$;- starch and TS: total sugars.

\subsubsection{Statistical analysis}

Three replicates were maintained for each experiment and duplicate analyses performed on each replicate. The data were subjected to Analysis of Variance (ANOVA) for statistical testing of the mean values and the least significant difference (LSD) for pair-wise comparison of mean values was worked out using the statistical package,[36].

\section{RESULTS AND DISCUSSION}

\subsection{Compositional profile of native biomass}

The compositional profile of peels from beet root (BP), greater yam (GYP), Pumpkin (PP) and vegetable banana (VBP) is presented in Table 1. Highest cellulose contents were observed in VBP and PP while the other two biomass residues had similar (18-19\%) cellulose contents. Hemicellulose, on the contrary was higher in GYP and $\mathrm{BP}$ and the lowest in VBP. Very high starch content of $36.6 \%$ was obtained for VBP while the other residues had starch in the range of $24-29 \%$ (Table 1). Lignin content was the highest $(10.6 \%)$ in PP and VBP, while BP had very low lignin content. Ash content ranged from 3.3 to $5.7 \%$. Total and reducing sugar contents were the highest in the beet root peel, accounting for $17 \%$ and $7 \%$ of dry weight respectively. Despite the highest starch content, sugar content was the lowest in VBP.

Most of the studies reported on the bioethanol production potential of banana peel are related to the ripe fruit banana or plantain and hitherto no studies are available on cooking banana (ABB group) peel. Okareh et al [9] (2015) reported that $M$. paradisiaca peel contained $68 \%$ carbohydrate and $8.9 \%$ ash, besides $10.4 \%$ crude fiber. We found that the VBP had a potential sugar yielding carbohydrate (PSYC) content of 77\% (comprising cellulose, hemicellulose, starch and total sugars), which is similar to that reported for plantain (AAB) group by Okareh et al. [9]. Besides there was very high starch content in VBP, while only 7.2\% starch (dry basis) was reported in desert banana (AAB) group by Mohapatra et al [11] . Total carbohydrate and fiber contents of $59 \%$ and $8.2 \%$ were reported in $M$. sapientum peel by $\mathrm{Xu}$ et al
[26]. They also reported that the peel contained $8.5 \%$ ash which was much higher than $3.40 \%$ observed in VBP in our study. Chantawongsa and Kongkiattikajorn [37] reported total carbohydrate content of $60.8 \%$ in banana peel with a high starch content of $32.75 \%$ similar to our study. Lignin content in VBP $(10.6 \%)$ was in the range reported for plantain and fruit banana peels [11,37]. It was found that pumpkin (C. moschata) and greater yam peels were also rich sources of carbohydrate $(72.13 \%$ and $71.2 \%$ respectively comprising cellulose, $\mathrm{HC}$, starch and TS), while $74-75 \%$ carbohydrate has been reported for pumpkin peel by others [15]. Out of the total sugars, 74.5 $\%$ existed as reducing sugars (RS) in pumpkin peel which was much higher than $40.5 \%$ in beer root peel, $50 \%$ in GYP and $61.7 \%$ in VBP (Table 1). There are no reports on the compositional profile of the peel of garden beet. Nevertheless, Zheng et al. [38] reported that the dry pulp from sugar beet after extraction of sucrose contained 86$87 \%$ carbohydrate and 1-2\% lignin and its potential as a biofuel source has been reported [38]. The low lignin content in BP and GYP might be advantageous during the saccharification stage, as it could reduce the chances of inhibition of cellulase by lignin byproducts formed during pretreatment [39].

\subsection{Polysaccharide changes during pretreatments}

The changes in the structural (cellulose and hemicellulose) and non-structural polysaccharides in the selected biomass after the three pretreatment methods indicated that very high extent of starch hydrolysis occurred during DSA pretreatment in all the residues (Table 2). Proportionate increase in starch hydrolysis was observed when DSA pretreatment time was extended to 60 min. High starch hydrolysis was also observed in P2 (40\% MC steam treated for $45 \mathrm{~min}$.). It was found that approximately $94-95 \%$ starch was hydrolyzed in the various DSA pretreated (60 $\mathrm{min}$ ) biomasses, while only $35-37 \%$ reduction occurred in P2 (Table 3). We had earlier reported $94 \%$ reduction in DSA pretreated biomass such as peels of sweet potato, elephant foot yam, tannia and ash gourd as well as in mixed vegetable wastes from households/ restaurants [28] while only up to $25 \%$ and $5 \%$ hydrolysis respectively were observed in steam (60 min.) and lime pretreatments. Maximum hydrolysis of hemicellulose occurred in ST (P3 and P6; Tables 2 and 3), which was similar to those reported earlier[28].

Table 1: Compositional profile of the selected root and vegetable processing residues (expressed as $\mathrm{g} / 100 \mathrm{~g} d r y$ basis)*

\begin{tabular}{|c|c|c|c|c|}
\hline Parameters & Beet root peel & Greater yam & Pumpkin peel & Vegetable banana \\
\hline Ash & $5.66 \pm 0.10$ & $3.29 \pm 0.24$ & $4.22 \pm 0.06$ & $3.40 \pm 0.08$ \\
\hline Lignin & $3.87 \pm 0.34$ & $6.72 \pm 0.17$ & $10.66 \pm 0.84$ & $10.55 \pm 0.33$ \\
\hline Cellulose & $18.94 \pm 0.20$ & $18.02 \pm 0.58$ & $21.05 \pm 0.79$ & $22.40 \pm 0.64$ \\
\hline Hemicellulose & $19.17 \pm 0.55$ & $20.02 \pm 0.57$ & $17.74 \pm 0.47$ & $15.19 \pm 0.56$ \\
\hline
\end{tabular}




\begin{tabular}{|c|c|c|c|c|}
\hline Starch & $27.13 \pm 0.00$ & $28.84 \pm 0.44$ & $24.61 \pm 0.00$ & $36.56 \pm 0.00$ \\
\hline Total sugars & $17.07 \pm 0.12$ & $4.33 \pm 0.00$ & $8.73 \pm 0.06$ & $2.77 \pm 0.01$ \\
\hline PSYC** & 82.31 & 71.21 & 72.13 & 76.92 \\
\hline Reducing sugars & $6.91 \pm 0.04$ & $2.17 \pm 0.00$ & $6.50 \pm 0.00$ & $1.71 \pm 0.00$ \\
\hline Others $* * * *$ & 8.16 & 18.78 & 13.00 & 9.13 \\
\hline
\end{tabular}

*Each value is Mean \pm SD from three replicates; ** PSYC- potential sugar yielding carbohydrate comprises cellulose+ hemicellulose+ starch+ total sugars; *** figures in parentheses indicate percentage of TS existing as RS; **** Others include residual moisture, protein, extractives, bioactives such as phenols etc.

Cellulose was also hydrolysed to a higher extent (27-29 $\%$ ) in these pretreatments, while only negligible hydrolysis was observed in the DSA and lime pretreated biomass residues (Table 3 ). There are reports that cellulose is only slowly attacked by DSA and is soluble in alkalis [39]. Approximately $42-43 \%$ hemicellulose was hydrolysed during DSA (60 min.) pretreatment (Table 3). Saha and Bothast [41 ]also found that pretreatment of corn fiber with $0.5 \%$ DSA $\left(121{ }^{\circ} \mathrm{C}\right)$ had the highest effect in hydrolyzing hemicellulose and starch. Dilute sulfuric acid is reported to hydrolyze hemicellulose, leaving a residue that is rich in cellulose and lignin. Removal of hemicellulose is reported to weaken the carbohydratelignin matrix, thereby enhancing the accessibility of cellulose $[42,43]$. The findings from the present study are supportive of the earlier reports. Prolonging the exposure time of wet biomass to steam from $45 \mathrm{~min}$. to $60 \mathrm{~min}$. resulted in retention of more starch, possibly because of the transformation of starch to resistant form especially under the acidic $\mathrm{pH}$ due to the hydrolysis of hemiacetal groups from hemicellulose. Such a reversion was reported earlier in steam pretreated cassava starch factory waste and processing residues of cassava as well as in the peels from sweet potato, elephant foot yam, tannia and ash gourd [28,44,45].

Lime pretreatment resulted in the removal of only smaller quantities of cellulose, hemicellulose and starch, with much of the starch being retained in the water insoluble solid (WIS) fraction (Table 2) and the pattern was similar for the various residues irrespective of the variations in the original profile. While cellulose was removed to the extent of $1.2-10 \%$ by the three types of lime pretreatment, hemicellulose was solubilized to a higher extent (7.6$13 \%$ ), with higher values for $24 \mathrm{~h}$ RT lime treatment and starch solubilization ranged from 0.20 to $4.8 \%$ only (Table 3). We had earlier reported similar pattern of removal of structural and non-structural polysaccharides during lime pretreatment of peels of sweet potato, elephant foot yam, tannia and ash gourd [29]. Kim and Holtzapple [46] reported solubilization of only $6.3 \%$ glucans and $21 \%$ xylan after 16 weeks lime pretreatment $(0.5 \mathrm{~g} / \mathrm{g}$ biomass $)$ of corn stover. Chang et al. [47] found that $0.1 \mathrm{~g} / \mathrm{g}$ dry biomass was the optimum for lime loading for sugarcane bagasse and the same was used in our study as well.

Among the three pretreatments, DSA resulted in the hydrolysis of very high amounts of starch and reasonably good quantities of hemicellulose, while hemicellulose was hydrolyzed to a greater extent in $60 \mathrm{~min}$. steam pretreatment ( $40 \%$ and $50 \% \mathrm{MC}$ ). Since starch is a major component of the selected biomasses, DSA pretreatment $\left(121{ }^{\circ} \mathrm{C} ; 0.102 \mathrm{MPa}\right)$ at moderate level $(0.5 \% \mathrm{v} / \mathrm{v})$ and time (30-60 min.) could be considered beneficial as it could reduce the amylase loading coupled with low xylanase requirement at the saccharification stage, leading to saving of enzyme costs.

\subsection{Delignification in pretreated biomass}

Maximum reduction in lignin was observed in P3 (40\% MC; $60 \mathrm{~min}$.) and P6 (50\% MC; $60 \mathrm{~min}$.) for all the four biomasses (Table 4). Delignification percentage ranged from $28-37 \%$ in these pretreatments. Dilute sulfuric acid (60 min.) brought about only $8.7-14 \%$ delignification, while least effect was observed in the case of all the three lime pretreatments (Fig. $1 \mathrm{a}-\mathrm{d}$ ). As the native untreated BP was found to contain only $3.87 \%$ lignin, the very low extent of delignification obtained in DSA and lime pretreatments might not pose a problem during saccharification.

Table 2: Structural and non-structural polysaccharide changes* in steam, DSA and lime pretreated root and vegetable processing residues (expressed as g/100 g original material on dry basis)

\begin{tabular}{|c|c|c|c|c|c|c|c|c|c|c|c|c|}
\hline \multirow{2}{*}{$\begin{array}{l}\text { Pretreatmen } \\
\text { ts }\end{array}$} & \multicolumn{3}{|c|}{ Beet root peel (BP) } & \multicolumn{3}{|c|}{$\begin{array}{l}\text { Greater yam } \\
\text { peel(GYP) }\end{array}$} & \multicolumn{3}{|c|}{ Pumpkin peel (PP) } & \multicolumn{3}{|c|}{$\begin{array}{c}\text { Vegetable banana peel } \\
\text { (VBP) }\end{array}$} \\
\hline & $\mathbf{C}$ & HC & ST & $\mathbf{C}$ & $\mathrm{HC}$ & ST & $\mathbf{C}$ & HC & ST & $\mathbf{C}$ & $\mathrm{HC}$ & ST \\
\hline Native & $18.94^{\mathrm{a}}$ & $19.17^{\mathrm{a}}$ & $27.13^{\mathrm{a}}$ & $18.02^{\mathrm{a}}$ & $20.02^{\mathrm{a}}$ & $28.84^{\mathrm{a}}$ & $21.05^{\mathrm{a}}$ & $17.74^{\mathrm{a}}$ & $24.61^{\mathrm{a}}$ & $22.40^{\mathrm{a}}$ & $15.19^{\mathrm{a}}$ & $36.56^{\mathrm{a}}$ \\
\hline
\end{tabular}




\begin{tabular}{|c|c|c|c|c|c|c|c|c|c|c|c|c|}
\hline P1 (30 min.) & $17.71^{\mathrm{bc}}$ & $15.43^{\mathrm{d}}$ & $20.08^{\mathrm{d}}$ & $16.51^{\mathrm{b}}$ & $15.77^{\mathrm{d}}$ & $21.00^{\mathrm{d}}$ & $19.72^{\mathrm{b}}$ & $14.75^{\mathrm{c}}$ & $18.27^{\mathrm{d}}$ & $21.24^{\mathrm{bc}}$ & $12.63^{\mathrm{d}}$ & $27.15^{\mathrm{d}}$ \\
\hline P2 (45 min.) & $16.96^{\mathrm{de}}$ & $14.97^{\mathrm{d}}$ & $17.27^{\mathrm{e}}$ & $15.87^{\mathrm{c}}$ & $15.37^{\mathrm{d}}$ & $18.09^{\mathrm{e}}$ & $18.94^{\mathrm{de}}$ & $14.47^{\mathrm{d}}$ & $15.63^{\mathrm{e}}$ & $20.09^{\mathrm{e}}$ & $12.37^{\mathrm{e}}$ & $23.57^{\mathrm{e}}$ \\
\hline P3 (60 min.) & $13.70^{\mathrm{g}}$ & $9.25^{\mathrm{g}}$ & $20.67^{\mathrm{d}}$ & $12.83^{\mathrm{d}}$ & $9.45^{\mathrm{g}}$ & $21.76^{\mathrm{d}}$ & $15.43^{\mathrm{g}}$ & $8.24^{\mathrm{g}}$ & $18.77^{\mathrm{d}}$ & $16.40^{\mathrm{g}}$ & $7.14^{\mathrm{h}}$ & $27.56^{\mathrm{d}}$ \\
\hline \multicolumn{13}{|c|}{ Steam pretreatment (50\% MC) } \\
\hline P4 (30 min.) & $17.55^{\mathrm{cd}}$ & $14.92^{\mathrm{b}}$ & $22.01^{\mathrm{c}}$ & 16.50 & $15.38^{\mathrm{d}}$ & $23.19^{\mathrm{c}}$ & $19.41^{\text {cd }}$ & $14.39^{\mathrm{d}}$ & $20.00^{c}$ & $20.60^{\text {de }}$ & $12.43^{\mathrm{d}}$ & $29.30^{\mathrm{c}}$ \\
\hline P5 (45 min.) & $16.02^{\mathrm{f}}$ & $14.42^{\mathrm{e}}$ & $20.08^{\mathrm{d}}$ & $15.04^{\mathrm{c}}$ & $14.86^{\mathrm{d}}$ & $21.13^{\mathrm{d}}$ & $17.86^{\mathrm{f}}$ & $13.29^{\mathrm{e}}$ & $18.21^{\mathrm{d}}$ & $19.30^{\mathrm{f}}$ & $11.48^{\mathrm{f}}$ & $27.12^{\mathrm{d}}$ \\
\hline P6 (60 min.) & $13.65^{\mathrm{g}}$ & $8.74^{\mathrm{g}}$ & $22.16^{\mathrm{c}}$ & $12.78^{\mathrm{d}}$ & $8.92^{\mathrm{gh}}$ & $23.35^{\mathrm{c}}$ & $15.20^{\mathrm{g}}$ & $8.11^{\mathrm{g}}$ & $20.16^{\mathrm{c}}$ & $16.05^{\mathrm{g}}$ & $6.90^{\mathrm{h}}$ & $29.65^{\mathrm{c}}$ \\
\hline \multicolumn{13}{|c|}{$\mathrm{DSA}\left(121^{\circ} \mathrm{C}\right.$ and $\left.0.102 \mathrm{MPa}\right)$} \\
\hline $30 \mathrm{~min}$. & $16.42^{\mathrm{ef}}$ & $14.61^{\mathrm{e}}$ & $4.48^{\mathrm{f}}$ & $15.76^{\mathrm{c}}$ & $15.39^{\mathrm{d}}$ & $4.89^{\mathrm{f}}$ & $18.03^{\text {ef }}$ & $13.25^{\mathrm{e}}$ & $4.15^{\mathrm{f}}$ & $19.37^{f}$ & $11.57^{\mathrm{f}}$ & $6.06^{\mathrm{f}}$ \\
\hline 60 min. & $16.04^{\mathrm{f}}$ & $11.10^{\mathrm{f}}$ & $1.61^{\mathrm{g}}$ & $15.40^{\mathrm{c}}$ & $11.72^{\mathrm{f}}$ & $1.84^{\mathrm{g}}$ & $17.38^{\mathrm{f}}$ & $10.22^{\mathrm{f}}$ & $1.25^{\mathrm{g}}$ & $18.79^{\mathrm{f}}$ & $8.66^{\mathrm{g}}$ & $2.15^{\mathrm{g}}$ \\
\hline \multicolumn{13}{|c|}{ Lime $\mathrm{HT}\left(121^{\circ} \mathrm{C}\right.$ and $\left.0.102 \mathrm{MPa}\right)$} \\
\hline $30 \mathrm{~min}$. & $17.51^{\mathrm{cd}}$ & $17.23^{\mathrm{b}}$ & $27.00^{\mathrm{a}}$ & $16.51^{\mathrm{b}}$ & $17.84^{\mathrm{b}}$ & $28.54^{\mathrm{a}}$ & $19.27^{\mathrm{cd}}$ & $15.75^{\mathrm{b}}$ & $24.47^{\mathrm{a}}$ & $20.52^{\mathrm{de}}$ & $13.46^{\mathrm{c}}$ & $36.37^{\mathrm{a}}$ \\
\hline 60 min. & $18.71^{\mathrm{a}}$ & $17.71^{\mathrm{b}}$ & $26.50^{\mathrm{a}}$ & $17.65^{\mathrm{b}}$ & $18.34^{\mathrm{b}}$ & $28.01^{\mathrm{a}}$ & $20.61^{\mathrm{ab}}$ & $16.19^{\mathrm{b}}$ & $24.00^{\mathrm{a}}$ & $21.94^{\mathrm{b}}$ & $13.84^{\mathrm{b}}$ & $35.70^{\mathrm{a}}$ \\
\hline \multicolumn{13}{|c|}{ Lime $\mathrm{LT}\left(50^{\circ} \mathrm{C}\right)$} \\
\hline $6 \mathrm{~h}$ & $17.82^{\mathrm{bc}}$ & $17.53^{\mathrm{b}}$ & $27.07^{\mathrm{a}}$ & $16.80^{\mathrm{b}}$ & $18.15^{\mathrm{b}}$ & $28.61^{\mathrm{a}}$ & $19.62^{\mathrm{bc}}$ & $16.03^{b}$ & $24.52^{\mathrm{a}}$ & $20.89^{\mathrm{cd}}$ & $13.69^{\mathrm{b}}$ & $36.47^{\mathrm{a}}$ \\
\hline $24 \mathrm{~h}$ & $18.31^{\mathrm{ab}}$ & $17.34^{\mathrm{b}}$ & $26.00^{\mathrm{a}}$ & $17.27^{\mathrm{b}}$ & $17.95^{\mathrm{b}}$ & $27.48^{\mathrm{a}}$ & $20.16^{\mathrm{bc}}$ & $16.05^{\mathrm{b}}$ & $23.60^{\mathrm{a}}$ & $21.46^{\mathrm{bc}}$ & $13.54^{\mathrm{c}}$ & $35.10^{\mathrm{a}}$ \\
\hline \multicolumn{13}{|c|}{ Lime RT $\left(30 \pm 1^{\circ} \mathrm{C}\right)$} \\
\hline $24 \mathrm{~h}$ & $17.21^{\mathrm{cd}}$ & $16.86^{\mathrm{c}}$ & $25.97^{\mathrm{a}}$ & $16.22^{\mathrm{b}}$ & $17.46^{\mathrm{b}}$ & $27.44^{\mathrm{a}}$ & $19.04^{\mathrm{d}}$ & $15.41^{\mathrm{b}}$ & $23.50^{\mathrm{a}}$ & $20.17^{\mathrm{e}}$ & $13.17^{\mathrm{c}}$ & $35.00^{\mathrm{a}}$ \\
\hline $48 \mathrm{~h}$ & $17.93^{\mathrm{bc}}$ & $17.45^{\mathrm{b}}$ & $26.90^{\mathrm{a}}$ & $16.91^{\mathrm{b}}$ & $18.07^{\mathrm{b}}$ & $28.44^{\mathrm{a}}$ & $19.74^{\mathrm{bc}}$ & $16.06^{\mathrm{b}}$ & $24.43^{\mathrm{a}}$ & $21.01^{\mathrm{cd}}$ & $13.63^{\mathrm{b}}$ & $36.33^{\mathrm{a}}$ \\
\hline
\end{tabular}

*Each value is mean from three replicates; statistical comparison was made with the respective values in the native sample for each biomass; means with different superscripts in each column are significant at $\mathrm{p}<0.05$; MC- moisture content

Among the three types of lime pretreatments, highest delignification was in $24 \mathrm{~h}$ RT for the various biomasses (Table 4 and Fig. 1 a-d). Lime is reported to enhance the removal of acetyl groups and breakdown the lignincarbohydrate ester linkages, resulting in the reduction in cellulose crystallinity [4]. Besides, the divalent calcium ions are reported to form effective crosslinking with lignin, which therefore remains in the pretreated residue itself without getting solubilized [48]. Under the alkaline $\mathrm{pH}$, carboxyl, methoxy and hydroxyl groups of lignin become ionized and assume negative charge, which facilitates its binding to calcium [49].

Table 3:Percentage reduction* in the structural and non-structural polysaccharides due to steam, DSA and lime pretreatment in root and vegetable processing residues

\begin{tabular}{|c|c|c|c|c|c|c|c|c|c|c|c|c|}
\hline \multirow{2}{*}{$\begin{array}{l}\text { Pretreatment } \\
\text { S }\end{array}$} & \multicolumn{3}{|c|}{ Beet root peel (BP) } & \multicolumn{3}{|c|}{ Greater yam peel } & \multicolumn{3}{|c|}{ Pumpkin peel (PP) } & \multicolumn{3}{|c|}{ Vegetable banana peel } \\
\hline & $\mathbf{C}$ & HC & ST & $\mathbf{C}$ & $\mathbf{H C}$ & ST & $\mathbf{C}$ & HC & ST & $\mathbf{C}$ & HC & ST \\
\hline \multicolumn{13}{|c|}{ Steam pretreatment $(40 \% \mathrm{MC})$} \\
\hline P1 (30 min.) & $6.50^{\mathrm{ef}}$ & $19.52^{\mathrm{d}}$ & $\begin{array}{c}26.00 \\
\mathrm{~d}\end{array}$ & $8.39^{\mathrm{g}}$ & $\begin{array}{c}21.22 \\
\mathrm{f}\end{array}$ & $27.18^{\mathrm{d}}$ & $\begin{array}{c}6.32^{\mathrm{cd}} \\
\mathrm{e}\end{array}$ & $\begin{array}{c}16.83^{\mathrm{d}} \\
\mathrm{e}\end{array}$ & $\begin{array}{c}25.79^{\mathrm{d}} \\
\mathrm{e} \\
\end{array}$ & $5.20^{\mathrm{e}}$ & $\begin{array}{c}16.87^{\mathrm{d}} \\
\mathrm{e}\end{array}$ & $25.73^{\mathrm{d}}$ \\
\hline P2 (45 min.) & $\begin{array}{c}10.45^{\mathrm{c}} \\
\mathrm{d}\end{array}$ & $\begin{array}{c}21.90^{\mathrm{c}} \\
\mathrm{d}\end{array}$ & $\begin{array}{c}36.33 \\
c\end{array}$ & $\begin{array}{c}11.95 \\
\mathrm{e}\end{array}$ & $\begin{array}{c}23.25 \\
\mathrm{e}\end{array}$ & $37.26^{\mathrm{c}}$ & 10.03 & $18.44^{\mathrm{d}}$ & $36.51^{\mathrm{c}}$ & $10.34^{\mathrm{c}}$ & $18.59^{\mathrm{d}}$ & $35.54^{\mathrm{c}}$ \\
\hline P3 (60 min.) & $27.65^{\mathrm{a}}$ & $51.73^{\mathrm{a}}$ & $\begin{array}{c}23.82 \\
\mathrm{e}\end{array}$ & $\begin{array}{c}28.82 \\
\mathrm{a} \\
\end{array}$ & $\begin{array}{c}52.78 \\
\mathrm{~b}\end{array}$ & $24.55^{\mathrm{f}}$ & $\begin{array}{c}26.73 \\
a \\
\end{array}$ & $53.54^{\mathrm{a}}$ & $23.73^{\mathrm{f}}$ & $26.81^{\mathrm{a}}$ & $53.02^{\mathrm{a}}$ & $\begin{array}{c}24.62^{\mathrm{d}} \\
\mathrm{e}\end{array}$ \\
\hline \multicolumn{13}{|c|}{ Steam pretreatment (50\% MC) } \\
\hline P4 (30 min.) & $7.30^{\mathrm{de}}$ & $\begin{array}{c}22.15^{\mathrm{c}} \\
\mathrm{d}\end{array}$ & $\begin{array}{c}18.86 \\
\mathrm{f}\end{array}$ & $8.46^{\mathrm{g}}$ & $\begin{array}{c}23.20 \\
\mathrm{e}\end{array}$ & $19.58^{\mathrm{g}}$ & $7.83^{\mathrm{cd}}$ & $18.86^{\mathrm{d}}$ & $18.73^{\mathrm{g}}$ & $8.06^{\mathrm{cd}}$ & $18.19^{\mathrm{d}}$ & $19.86^{\mathrm{f}}$ \\
\hline P5 (45 min.) & $15.38^{\mathrm{b}}$ & $24.74^{\mathrm{c}}$ & $\begin{array}{c}26.00 \\
d\end{array}$ & $\begin{array}{c}16.54 \\
b\end{array}$ & $\begin{array}{c}25.79 \\
\mathrm{~d}\end{array}$ & $\begin{array}{c}26.73^{\mathrm{d}} \\
\mathrm{e}\end{array}$ & $\begin{array}{c}15.15 \\
b\end{array}$ & $25.09^{\mathrm{c}}$ & $26.04^{\mathrm{d}}$ & $13.84^{\mathrm{b}}$ & $24.43^{\mathrm{c}}$ & $25.83^{\mathrm{d}}$ \\
\hline P6 (60 min.) & $27.92^{\mathrm{a}}$ & $54.39^{\mathrm{a}}$ & $\begin{array}{c}18.30 \\
\mathrm{f}\end{array}$ & $\begin{array}{c}29.08 \\
a\end{array}$ & $\begin{array}{c}55.44 \\
\mathrm{a}\end{array}$ & $19.03^{\mathrm{g}}$ & $\begin{array}{c}27.82 \\
a\end{array}$ & $54.29^{\mathrm{a}}$ & $18.11^{\mathrm{g}}$ & $28.37^{\mathrm{a}}$ & $54.56^{\mathrm{a}}$ & $\begin{array}{c}18.89^{f} \\
g\end{array}$ \\
\hline \multicolumn{13}{|c|}{$\mathrm{DSA}\left(121^{\circ} \mathrm{C}\right.$ and $\left.0.102 \mathrm{MPa}\right)$} \\
\hline $30 \mathrm{~min}$. & $\begin{array}{c}13.28^{b} \\
c\end{array}$ & $23.75^{\mathrm{c}}$ & $\begin{array}{c}83.49 \\
\text { b }\end{array}$ & $\begin{array}{c}12.56 \\
\mathrm{~d}\end{array}$ & $\begin{array}{c}23.10 \\
\mathrm{e}\end{array}$ & $83.04^{\mathrm{b}}$ & $\begin{array}{c}14.39 \\
\mathrm{~b}\end{array}$ & $25.30^{c}$ & $83.14^{\mathrm{b}}$ & $13.55^{\mathrm{b}}$ & $23.81^{\mathrm{c}}$ & $83.42^{\mathrm{b}}$ \\
\hline 60 min. & $15.28^{\mathrm{b}}$ & $42.09^{\mathrm{b}}$ & $\begin{array}{c}94.06 \\
\mathrm{a} \\
\end{array}$ & $\begin{array}{c}14.56 \\
c\end{array}$ & $\begin{array}{c}41.44 \\
c\end{array}$ & $93.61^{\mathrm{a}}$ & $\begin{array}{c}17.44 \\
\mathrm{~b}\end{array}$ & $42.41^{\mathrm{b}}$ & $94.94^{\mathrm{a}}$ & $16.15^{\mathrm{b}}$ & $43.00^{\mathrm{b}}$ & $94.11^{\mathrm{a}}$ \\
\hline Lime HT (12 & and 0 & 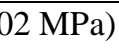 & & & & & & & & & & \\
\hline
\end{tabular}




\begin{tabular}{|c|c|c|c|c|c|c|c|c|c|c|c|c|}
\hline $30 \mathrm{~min}$. & $7.51^{\mathrm{de}}$ & $\begin{array}{c}10.10^{\mathrm{e}} \\
\mathrm{f}\end{array}$ & $0.48^{j}$ & $8.40^{\mathrm{g}}$ & $\begin{array}{c}10.90 \\
\mathrm{~h}\end{array}$ & $1.04^{\mathrm{j}}$ & $8.46^{\mathrm{cd}}$ & $11.23^{\mathrm{f}}$ & $0.60^{\mathrm{j}}$ & $8.41^{\mathrm{cd}}$ & $11.42^{\mathrm{f}}$ & $0.54^{\mathrm{j}}$ \\
\hline $60 \mathrm{~min}$. & $1.17^{\mathrm{g}}$ & $7.59^{f}$ & $2.32^{\mathrm{h}}$ & $2.06^{\mathrm{k}}$ & $8.38^{j}$ & $2.88^{\mathrm{i}}$ & $2.12^{\mathrm{e}}$ & $8.71^{\mathrm{f}}$ & $2.50^{\mathrm{i}}$ & $2.07^{\mathrm{f}}$ & $8.90^{f}$ & $2.36^{\mathrm{i}}$ \\
\hline \multicolumn{13}{|c|}{ Lime $\operatorname{LT}\left(50^{\circ} \mathrm{C}\right)$} \\
\hline $6 \mathrm{~h}$ & $5.88^{\mathrm{ef}}$ & $8.53^{f}$ & $0.24^{\mathrm{k}}$ & $6.77^{\mathrm{h}}$ & $9.33^{\mathrm{i}}$ & $0.79^{\mathrm{k}}$ & $6.83^{\mathrm{cd}}$ & $9.66^{f}$ & $0.40^{\mathrm{k}}$ & $6.77^{\mathrm{de}}$ & $9.85^{f}$ & $0.26^{\mathrm{k}}$ \\
\hline $24 \mathrm{~h}$ & $3.31^{\mathrm{fg}}$ & $9.56^{\mathrm{ef}}$ & $4.17^{\mathrm{g}}$ & $4.19^{j}$ & $\begin{array}{c}10.35 \\
h\end{array}$ & $4.72^{\mathrm{h}}$ & $4.26^{\mathrm{de}}$ & $9.56^{f}$ & $4.12^{\mathrm{h}}$ & $4.20^{\mathrm{ef}}$ & $10.87^{f}$ & $4.00^{\mathrm{h}}$ \\
\hline \multicolumn{13}{|c|}{ Lime RT $\left(30 \pm 1^{\circ} \mathrm{C}\right)$} \\
\hline $24 \mathrm{~h}$ & $9.09^{\mathrm{de}}$ & $12.01^{\mathrm{e}}$ & $4.29^{\mathrm{g}}$ & $9.98^{\mathrm{f}}$ & $\underset{\mathrm{g}}{12.81}$ & $4.84^{\mathrm{h}}$ & $9.57^{\mathrm{c}}$ & $\underset{\mathrm{f}}{13.14^{\mathrm{e}}}$ & $4.53^{\mathrm{h}}$ & $9.98^{c}$ & $13.33^{\mathrm{ef}}$ & $4.27^{\mathrm{h}}$ \\
\hline $48 \mathrm{~h}$ & $5.30^{\mathrm{ef}}$ & $8.93^{\text {ef }}$ & $0.84^{\mathrm{i}}$ & $5.89^{\mathrm{i}}$ & $\begin{array}{c}10.17 \\
\mathrm{~h}\end{array}$ & $1.49^{\mathrm{j}}$ & $\begin{array}{c}6.26^{\mathrm{cd}} \\
\mathrm{e}\end{array}$ & $9.50^{\mathrm{f}}$ & $0.74^{\mathrm{j}}$ & $6.20^{\mathrm{de}}$ & $10.25^{\mathrm{f}}$ & $0.63^{\mathrm{j}}$ \\
\hline
\end{tabular}

* Means with different superscripts in each column are significant at $\mathrm{p}<0.05$

3.4.Reducing sugar (RS) changes and pretreatment efficiency

Highest reducing sugar levels (g L-1 pretreated liquor) were obtained in the DSA pretreated biomass slurries, due to the high starch and hemicellulose hydrolysis (Table 5). Prolonging the pretreatment time from 30 to $60 \mathrm{~min}$. raised the RS level to $40-45 \mathrm{~g} \mathrm{~L}^{-1}$ in the various pretreated liquors. Among the ST pretreated liquors, the highest RS values were obtained for P3 (40\% MC; $60 \mathrm{~min})$. Least values were obtained for lime pretreated slurry, evidently due to the low starch and hemicellulose hydrolysis (Table 5). We had earlier reported similar trends for the RS content of ST, DSA and lime pretreated slurries of peels from sweet potato, elephant foot yam, tannia and ash gourd[28,29].

Table 4 : Lignin changes* in steam, DSA and lime pretreated root and vegetable processing residues (expressed as g/lo0 $g$ original material on dry basis).

\begin{tabular}{|c|c|c|c|c|}
\hline Pretreatments & $\begin{array}{l}\text { Beet root peel } \\
\text { (BP) }\end{array}$ & $\begin{array}{l}\text { Greater yam peel } \\
\text { (GYP) }\end{array}$ & $\begin{array}{l}\text { Pumpkin peel } \\
\text { (PP) }\end{array}$ & $\begin{array}{l}\text { Vegetable banana } \\
\text { peel } \\
\text { (VBP) }\end{array}$ \\
\hline Native & $3.87^{\mathrm{a}}$ & $6.72^{\mathrm{a}}$ & $10.66^{\mathrm{a}}$ & $10.55^{\mathrm{a}}$ \\
\hline \multicolumn{5}{|c|}{ Steam pretreatment (40\% MC) } \\
\hline P1 (30 min.) & $3.73^{\mathrm{abc}}$ & $6.14^{\mathrm{a}}$ & $10.42^{\mathrm{b}}$ & $9.73^{\mathrm{cd}}$ \\
\hline P2 (45 min.) & $3.44^{\text {cd }}$ & $5.70^{\mathrm{ab}}$ & $9.62^{\mathrm{cd}}$ & $9.03^{\mathrm{e}}$ \\
\hline P3 (60 min.) & $2.71^{\mathrm{f}}$ & $4.49^{\mathrm{c}}$ & $7.61^{\mathrm{f}}$ & $7.57^{\text {gh }}$ \\
\hline \multicolumn{5}{|c|}{ Steam pretreatment (50\% MC) } \\
\hline P4 (30 min.) & $3.28^{\mathrm{de}}$ & $5.48^{\mathrm{ab}}$ & $9.02^{\mathrm{e}}$ & $8.43^{f}$ \\
\hline P5 (45 min.) & $3.11^{\mathrm{e}}$ & $5.19^{\mathrm{b}}$ & $8.69^{\mathrm{e}}$ & $7.89^{\mathrm{g}}$ \\
\hline P6 (60 min.) & $2.56^{\mathrm{f}}$ & $4.23^{\mathrm{c}}$ & $7.11^{\mathrm{g}}$ & $7.19^{\mathrm{h}}$ \\
\hline \multicolumn{5}{|c|}{ DSA $\left(121^{\circ} \mathrm{C}\right.$ and $\left.0.102 \mathrm{MPa}\right)$} \\
\hline 30 min. & $3.63^{\mathrm{abc}}$ & $6.43^{\mathrm{a}}$ & $10.00^{\mathrm{bc}}$ & $10.00^{\mathrm{bc}}$ \\
\hline 60 min. & $3.46^{\mathrm{bcd}}$ & $6.14^{\mathrm{a}}$ & $9.15^{\mathrm{de}}$ & $9.37^{\mathrm{de}}$ \\
\hline \multicolumn{5}{|c|}{ Lime HT $\left(121^{\circ} \mathrm{C}\right.$ and $\left.0.102 \mathrm{MPa}\right)$} \\
\hline 30 min. & $3.84^{\mathrm{a}}$ & $6.52^{\mathrm{a}}$ & $10.40^{\mathrm{b}}$ & $10.29^{\mathrm{ab}}$ \\
\hline 60 min. & $3.75^{\mathrm{abc}}$ & $6.36^{\mathrm{a}}$ & $10.15^{\mathrm{bc}}$ & $10.04^{\mathrm{bc}}$ \\
\hline \multicolumn{5}{|c|}{ Lime LT $\left(50^{\circ} \mathrm{C}\right)$} \\
\hline $6 \mathrm{~h}$ & $3.86^{\mathrm{a}}$ & $6.54^{\mathrm{a}}$ & $10.43^{\mathrm{b}}$ & $10.32^{\mathrm{ab}}$ \\
\hline 24 h & $3.71^{\mathrm{abc}}$ & $6.28^{\mathrm{a}}$ & $10.02^{\mathrm{bc}}$ & $9.91^{\mathrm{bc}}$ \\
\hline \multicolumn{5}{|c|}{ Lime $\mathrm{RT}\left(30 \pm 1^{\circ} \mathrm{C}\right)$} \\
\hline $24 \mathrm{~h}$ & $3.63^{\mathrm{abc}}$ & $6.14^{\mathrm{a}}$ & $9.92^{\mathrm{bc}}$ & $9.70^{\text {cd }}$ \\
\hline $48 \mathrm{~h}$ & $3.83^{\mathrm{a}}$ & $6.50^{\mathrm{a}}$ & $10.37^{\mathrm{b}}$ & $10.26^{\mathrm{ab}}$ \\
\hline
\end{tabular}


* Statistical comparison was made with the native sample for each biomass; means with different superscripts in each column are significant at $\mathrm{p}<0.05$.

Accordingly, the pretreatment efficiency (\%) was also the highest for DSA pretreatment.As high as 57-64\% of the carbohydrates got converted to RS due to DSA pretreatment alone, which indicates that low enzyme loading might only be needed at the saccharification stage.Very low pretreatment efficiency (\%) of $9-13 \%$ only was observed in the lime pretreatment, while ST for
60 min. gave PE (\%) of 26-31\% (Table 6). Solids recovery was also the highest $(86-95 \%)$ from lime pretreatment, indicating the low biodegradation during pretreatment, while $40-68 \%$ and $40-60 \%$ residues respectively remained after ST and DSA pretreatments (data not shown) of the different biomasses.

Table 5: Reducing sugar content* in the pretreated liquor from steam, DSA and lime pretreated processing residues $\left(g L^{-1}\right.$ pretreated liquor)

\begin{tabular}{|c|c|c|c|c|}
\hline Pretreatments & $\begin{array}{l}\text { Beet root peel } \\
\text { (BP) }\end{array}$ & $\begin{array}{c}\text { Greater yam peel } \\
\text { (GYP) }\end{array}$ & $\begin{array}{c}\text { Pumpkin peel } \\
\text { (PP) }\end{array}$ & $\begin{array}{c}\text { Vegetable banana peel } \\
\text { (VBP) }\end{array}$ \\
\hline \multicolumn{5}{|c|}{ Steam pretreatment $(40 \% \mathrm{MC})$} \\
\hline P1 (30 min.) & $18.91^{\mathrm{g}}$ & $15.14^{\mathrm{g}}$ & $17.11^{\mathrm{e}}$ & $14.79^{\mathrm{g}}$ \\
\hline P2 (45 min.) & $22.90^{\mathrm{e}}$ & $19.10^{\mathrm{e}}$ & $20.22^{\mathrm{d}}$ & $19.70^{\mathrm{e}}$ \\
\hline P3 (60 min.) & $28.43^{\mathrm{c}}$ & $24.38^{\mathrm{c}}$ & $26.75^{\mathrm{c}}$ & $24.76^{\mathrm{c}}$ \\
\hline \multicolumn{5}{|c|}{ Steam pretreatment $(50 \% \mathrm{MC})$} \\
\hline P4 (30 min.) & $17.60^{\text {gh }}$ & $13.36^{\mathrm{h}}$ & $16.02^{\mathrm{ef}}$ & $13.54^{\text {gh }}$ \\
\hline P5 (45 min.) & $21.55^{\mathrm{f}}$ & $17.39^{\mathrm{f}}$ & $20.00^{\mathrm{d}}$ & $17.78^{\mathrm{f}}$ \\
\hline P6 (60 min.) & $27.51^{\mathrm{cd}}$ & $23.37^{\mathrm{cd}}$ & $26.34^{\mathrm{c}}$ & $23.11^{\mathrm{cd}}$ \\
\hline \multicolumn{5}{|c|}{$\mathrm{DSA}\left(121^{\circ} \mathrm{C}\right.$ and $\left.0.102 \mathrm{MPa}\right)$} \\
\hline $30 \mathrm{~min}$. & $36.00^{\mathrm{b}}$ & $32.40^{\mathrm{b}}$ & $33.40^{\mathrm{b}}$ & $38.00^{\mathrm{b}}$ \\
\hline $60 \mathrm{~min}$. & $43.00^{\mathrm{a}}$ & $39.48^{\mathrm{a}}$ & $40.56^{\mathrm{a}}$ & $45.00^{\mathrm{a}}$ \\
\hline \multicolumn{5}{|c|}{ Lime $\mathrm{HT}\left(121^{\circ} \mathrm{C}\right.$ and $\left.0.102 \mathrm{MPa}\right)$} \\
\hline $30 \mathrm{~min}$. & $10.32^{\mathrm{i}}$ & $6.07^{j}$ & $10.30^{\mathrm{g}}$ & $5.50^{j}$ \\
\hline $60 \mathrm{~min}$. & $8.63^{\mathrm{k}}$ & $4.96^{\mathrm{k}}$ & $9.00^{\text {gh }}$ & $4.20^{\mathrm{jk}}$ \\
\hline \multicolumn{5}{|l|}{ Lime $\operatorname{LT}\left(50^{\circ} \mathrm{C}\right)$} \\
\hline $6 \mathrm{~h}$ & $9.65^{\mathrm{ij}}$ & $5.40^{\mathrm{jk}}$ & $9.60^{\text {gh }}$ & $4.50^{\mathrm{jk}}$ \\
\hline $24 \mathrm{~h}$ & $9.56^{\mathrm{ij}}$ & $6.27^{j}$ & $10.00^{\mathrm{g}}$ & $5.60^{j}$ \\
\hline \multicolumn{5}{|c|}{ Lime RT $\left(30 \pm 1^{\circ} \mathrm{C}\right)$} \\
\hline $24 \mathrm{~h}$ & $10.52^{\mathrm{i}}$ & $7.84^{\mathrm{i}}$ & $11.58^{\mathrm{f}}$ & $7.30^{\mathrm{i}}$ \\
\hline $48 \mathrm{~h}$ & $9.65^{\mathrm{ij}}$ & $5.55^{\mathrm{jk}}$ & $9.58^{\mathrm{gh}}$ & $4.53^{\mathrm{jk}}$ \\
\hline
\end{tabular}

* Statistical comparison was made between treatments for each biomass; means with different superscripts in each column are significant at $\mathrm{p}<0.05$.

These studies showed that the pretreated liquor from DSA and ST pretreatments being rich in reducing sugars and that from lime pretreatment being viscous due to the swelling of cellulose and starch, separation of the liquid fraction from the solid could lead to either loss of RS in the former two pretreatments or make filtration difficult in the latter case. Hence saccharification of the $\mathrm{pH}$ adjusted whole slurry would be advisable. Nevertheless, 
formation of fermentation inhibitors such as furfural, 5hydroxyl methyl furfural and acetic acid has been reported in DSA pretreatments and an understanding of their levels in the selected biomasses, which is presently being studied and strategies to bring down the levels during downstream operations may be important.

Table 6: Pretreatment efficiency (\%)* in steam, DSA and lime pretreated root and vegetable processing residues

\begin{tabular}{|c|c|c|c|c|}
\hline Pretreatments & $\begin{array}{c}\text { Beet root peel } \\
(\mathrm{BP})\end{array}$ & $\begin{array}{c}\text { Greater yam peel } \\
\text { (GYP) }\end{array}$ & $\begin{array}{l}\text { Pumpkin peel } \\
\text { (PP) }\end{array}$ & $\begin{array}{c}\text { Vegetable banana peel } \\
\text { (VBP) }\end{array}$ \\
\hline \multicolumn{5}{|c|}{ Steam pretreatment $(40 \% \mathrm{MC})$} \\
\hline P1 (30 min.) & $17.09^{\mathrm{g}}$ & $16.66^{\mathrm{g}}$ & $17.59^{\mathrm{g}}$ & $19.70^{\mathrm{g}}$ \\
\hline P2 (45 min.) & $20.91^{\mathrm{e}}$ & $20.48^{\mathrm{e}}$ & $21.07^{\mathrm{e}}$ & $24.97^{\mathrm{e}}$ \\
\hline P3 (60 min.) & $27.14^{\mathrm{c}}$ & $26.71^{\mathrm{c}}$ & $29.20^{c}$ & $31.02^{\mathrm{c}}$ \\
\hline \multicolumn{5}{|c|}{ Steam pretreatment $(50 \% \mathrm{MC})$} \\
\hline P4 (30 min.) & $14.79^{\mathrm{h}}$ & $14.36^{\mathrm{h}}$ & $15.26^{\mathrm{h}}$ & $17.30^{\mathrm{h}}$ \\
\hline P5 (45 min.) & $19.28^{\mathrm{f}}$ & $18.85^{\mathrm{f}}$ & $20.72^{\mathrm{f}}$ & $22.49^{\mathrm{f}}$ \\
\hline P6 (60 min.) & $26.33^{\mathrm{d}}$ & $25.90^{\mathrm{cd}}$ & $28.99^{\mathrm{d}}$ & $29.21^{\mathrm{d}}$ \\
\hline \multicolumn{5}{|c|}{$\mathrm{DSA}\left(121^{\circ} \mathrm{C}\right.$ and $\left.0.102 \mathrm{MPa}\right)$} \\
\hline 30 min. & $58.60^{\mathrm{b}}$ & $57.13^{\mathrm{b}}$ & $57.40^{\mathrm{b}}$ & $60.00^{\mathrm{b}}$ \\
\hline 60 min. & $61.30^{\mathrm{a}}$ & $60.66^{\mathrm{a}}$ & $59.30^{\mathrm{a}}$ & $64.00^{\mathrm{a}}$ \\
\hline \multicolumn{5}{|c|}{ Lime HT $\left(121^{\circ} \mathrm{C}\right.$ and $\left.0.102 \mathrm{MPa}\right)$} \\
\hline $30 \mathrm{~min}$. & $12.87^{\mathrm{i}}$ & $11.97^{\mathrm{i}}$ & $12.19^{\mathrm{k}}$ & $10.87^{\mathrm{k}}$ \\
\hline $60 \mathrm{~min}$. & $11.38^{\mathrm{m}}$ & $10.48^{\mathrm{ij}}$ & $11.00^{\mathrm{n}}$ & $9.34^{\mathrm{m}}$ \\
\hline \multicolumn{5}{|l|}{ Lime $\operatorname{LT}\left(50^{\circ} \mathrm{C}\right)$} \\
\hline $6 \mathrm{~h}$ & $11.29^{\mathrm{n}}$ & $10.39^{\mathrm{ij}}$ & $12.19^{\mathrm{k}}$ & $9.16^{\mathrm{n}}$ \\
\hline $24 \mathrm{~h}$ & $11.86^{1}$ & $10.96^{\mathrm{ij}}$ & $11.00^{\mathrm{n}}$ & $9.56^{1}$ \\
\hline \multicolumn{5}{|c|}{ Lime RT $\left(30 \pm 1^{\circ} \mathrm{C}\right)$} \\
\hline $24 \mathrm{~h}$ & $12.75^{\mathrm{j}}$ & $11.85^{\mathrm{i}}$ & $12.57^{\mathrm{i}}$ & $11.54^{\mathrm{i}}$ \\
\hline $48 \mathrm{~h}$ & $12.59^{\mathrm{k}}$ & $11.69^{i}$ & $12.25^{\mathrm{j}}$ & $11.03^{j}$ \\
\hline
\end{tabular}

* Computed as given in Methods (Equation 2) based on the potential sugar yielding carbohydrates; means with different superscripts in each column are significant at $\mathrm{p}<0.05$.

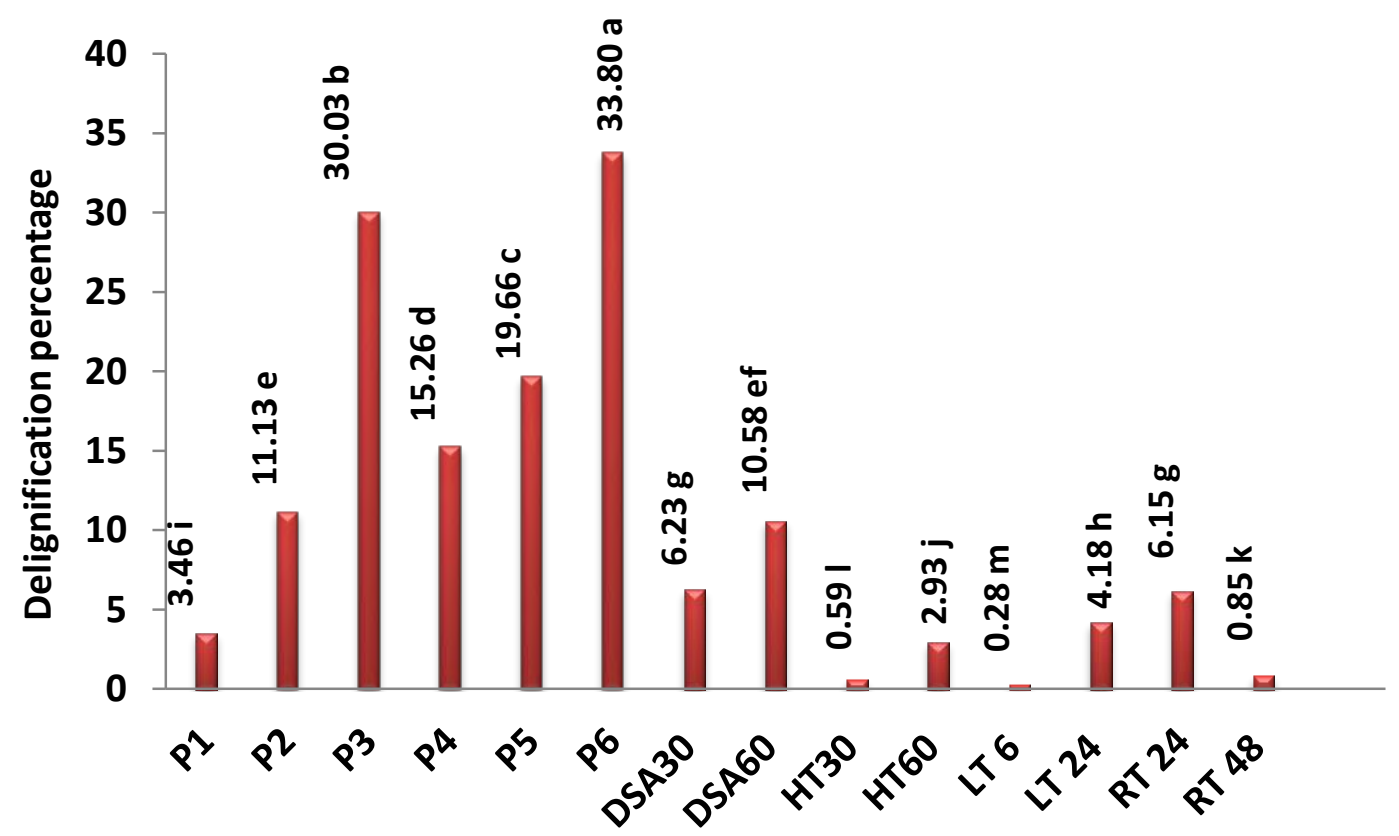

Fig.1a: Delignification in steam, DSA and lime pretreated beetroot peel Bars with different alphabets differ significantly at $p$ $<0.05$ 


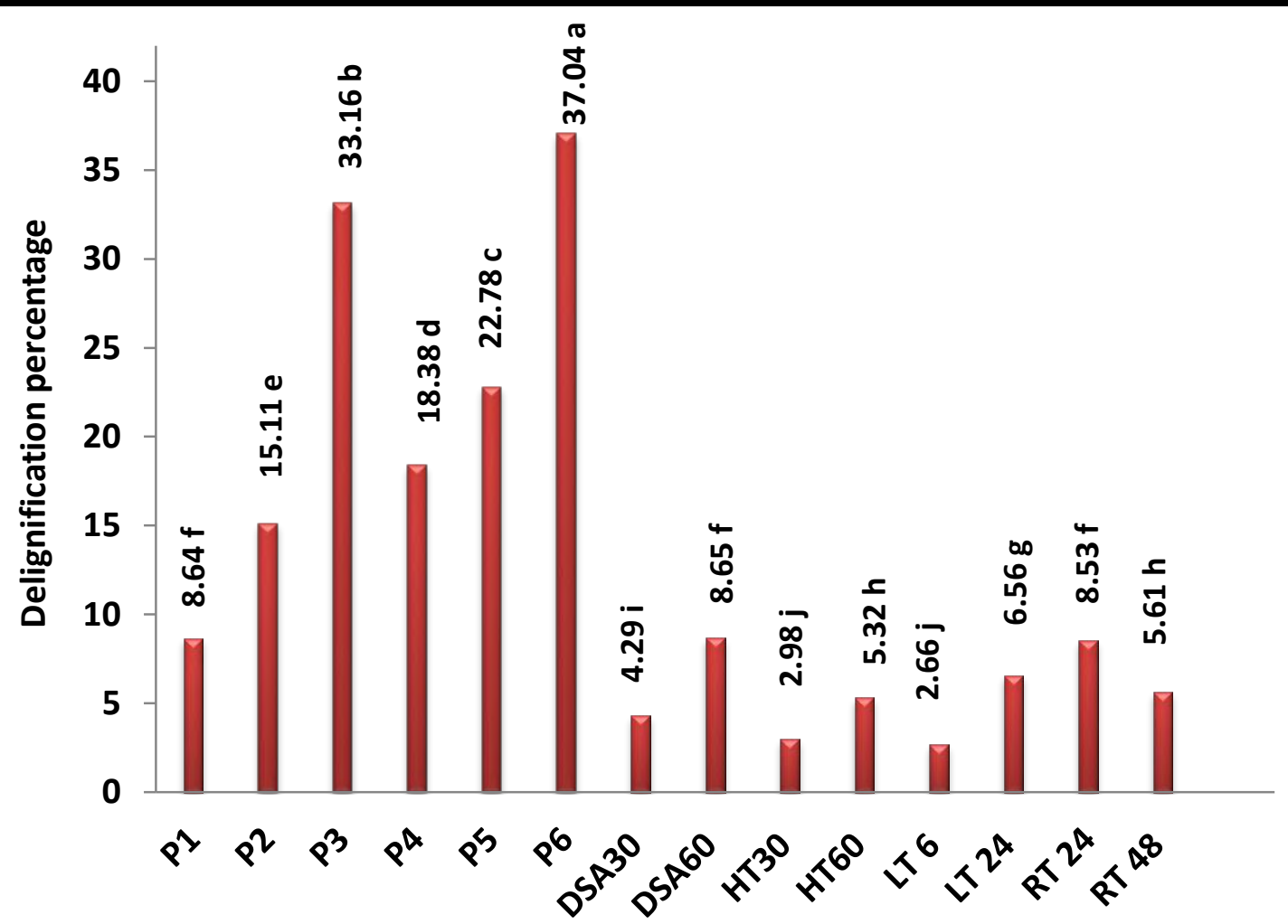

Fig.1 b: Delignification in steam, DSA and lime pretreated greater yam peel; other footnotes as in Fig. 1 a

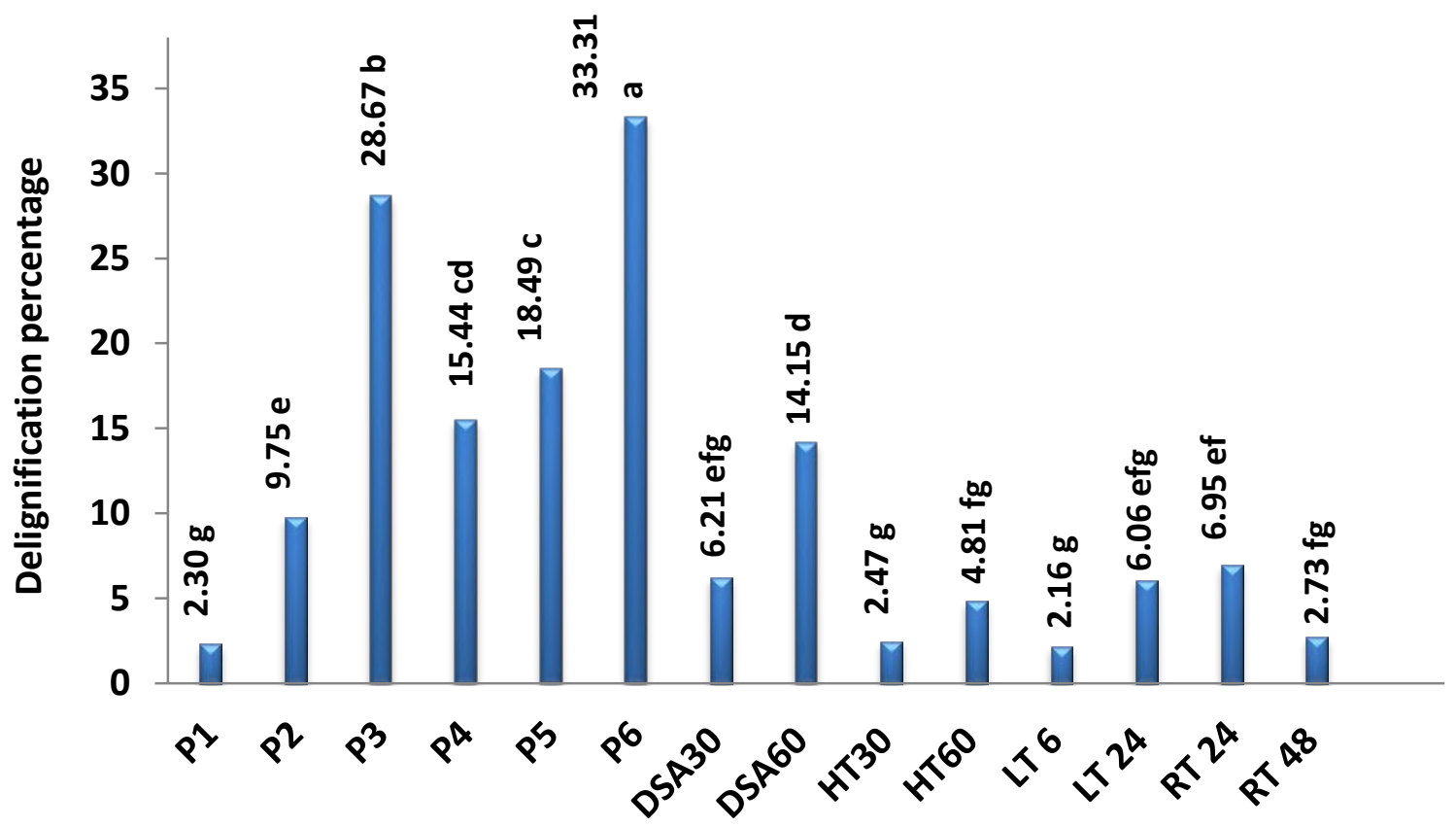

Fig. 1 c: Delignification in steam, DSA and lime pretreated pumpkin peel; other footnotes as in Fig. 1 a 


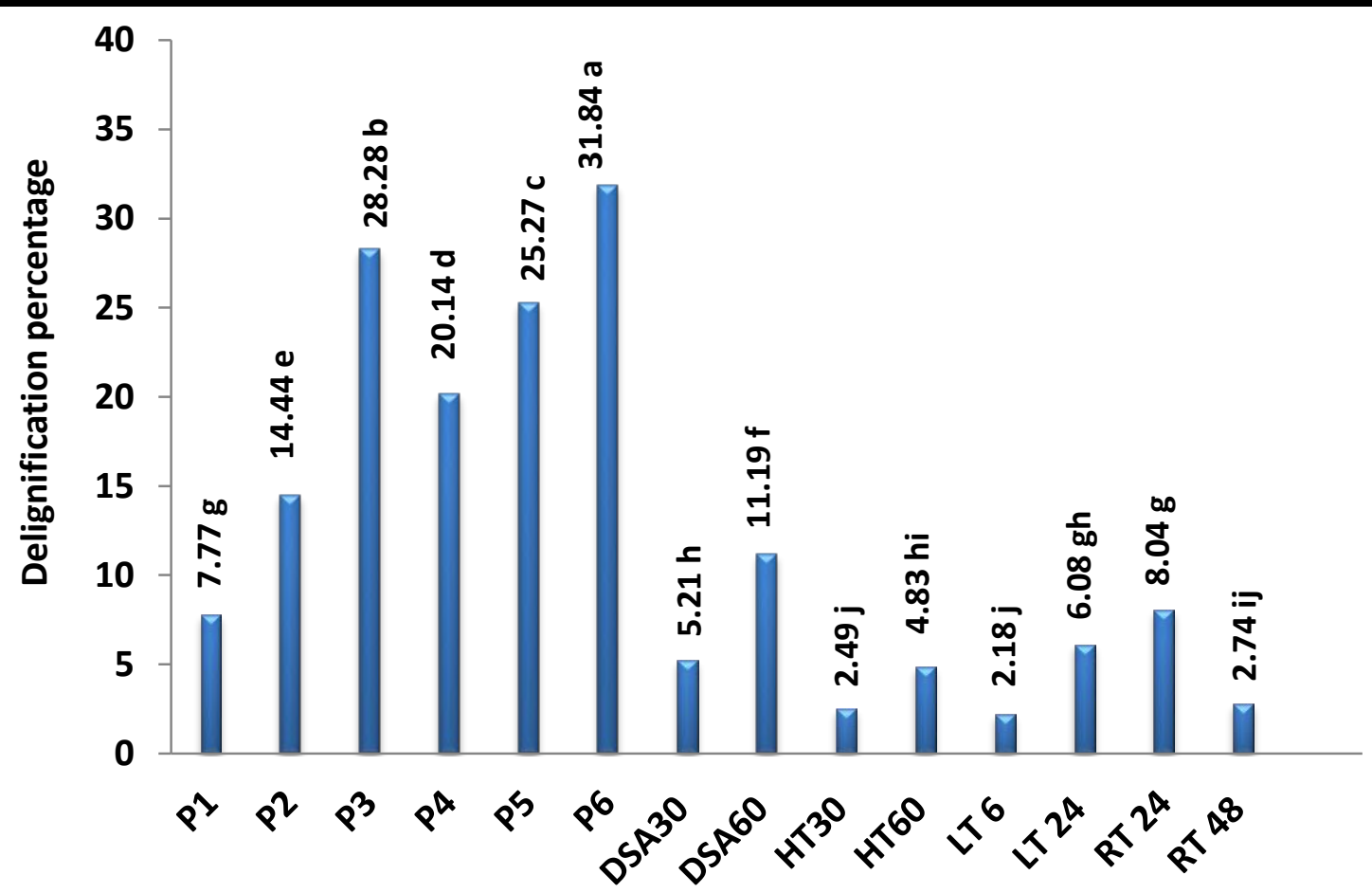

Fig.1 d: Delignification in steam, DSA and lime pretreated vegetable banana peel; other footnotes as in Fig. 1 a

\section{CONCLUSION}

The effect of three pretreatments such as steam, DSA and lime on the compositional changes in root and vegetable processing residues was investigated. It was found that the peels from beetroot, greater yam, pumpkin and vegetable banana were rich in starch (25-37\%) besides the structural polysaccharides, cellulose and hemicellulose. While DSA pretreatment for 60 min hydrolyzed starch to a very high extent ( $c a .95 \%)$ followed by hemicellulose (ca. 43\%), maximum hydrolysis of hemicellulose occurred in steam pretreatment $(60 \mathrm{~min})$. Lime pretreatment removed only small quantities of polysaccharides. Delignification was the highest in steam pretreated residues (28-37\%) while only $8.7-14 \%$ lignins were removed from DSA pretreated biomass. Pretreated liquor from DSA treatment had the highest reducing sugar levels followed by steam treatment, indicating the need for whole slurry saccharification.

\section{ACKNOWLEDGEMENTS}

The financial support from the Kerala State Council for Science, Technology \& Environment (KSCSTE) and the facilities provided by the Director, ICAR- CTCRI for the study are gratefully acknowledged. The enzymes, Spezyme and Stargen were supplied free of cost by $\mathrm{M} / \mathrm{s}$ Danisco US Inc., USA. We are also thankful to Dr. J. Sreekumar, Principal Scientist (Agricultural Statistics) for the help extended for statistical analyses.

\section{REFERENCES}

[1] Fuglestvedt, J, Berntsen, T, Myhre, G, Rypdal, K, Skeie, R.B. 2008." Climate forcing from the transport sectors". Proceedings of the National Academy of Science, U.S.A, 105, 454-458.

[2] Farrel, A.E, Pelvin, R.J, Turner, B.T, Jones, A.D, O'Hare, M, Kammen, D.M. 2006." Ethanol can contribute to energy and environmental goals". Science, 311: 506-508.

[3] Öhgren, K.H, Hahn, B, Zacchi, G. 2006. "Simultaneous saccharification and co-fermentation of glucose and xylose in steam pretreated corn stover at high fiber content with S. cerevisia".. Journal of Biotechnology, 126: 488-496.

[4] Mosier, M, Wyman, C.E, Dale, B, Elander, R, Lee, Y.Y, Holtzapple ,M. T, Ladisch, M.R. 2005. "Features of promising technologies for pretreatment of lignocellulosic biomass". Bioresource Technology, 96:673-686.

[5] Wyman, C.E.1999. "Biomass ethanol: Technical progress, opportunities and commercial challenges". Annual Review of Energy and the Environment, 24 :189-226.doi:1056-3466/99/1022-0189\$12.00.

[6] Holtzapple, M.T, Ripley, E.P, Nikolaou, M.1994. "Saccharification, fermentation, and protein recovery from low-temperature AFEX-treated coastal Bermuda grass". Biotechnology and Bioengineering, 44 : 1122-1131. 
[7] FAOSTAT,2013

http://faostat.fao.org/site/567/DesktopDefault .aspx?PagelD=567\#ancor downloaded on 18 December, 2015.

[8] Emaga, T.H, Robert, C, Ronkart, S.N, Wathelet, B, Paquot, M. 2008. "Dietary fibre component and pectin chemical features of peels during ripening in banana and plantain varieties". Bioresource Technology, 99: 4346-4354.

[9] Okareh, O.T, Adeolu, A.T, Adepoju, O.T. 2015. “ Proximate and mineral composition of plantain (Musa paradisiaca) wastes flour: a potential nutrients source in the formulation of animal feeds". African Journal of Food Science and Technology, 6(2):5357.

[10] Aarti, D, Anita, C. 2010. "Utilization of banana peels and beet waste for alcohol production". Asiatic Journal of Biotechological Research 1071:8-13.

[11] Mohapatra, D, Mishra, S, Sutar, N. 2010. "Banana and its byproduct utilization: an overview". Journal of Science and Industrial Research, 69: 323-329.

[12] Shyam Kumar, R, Ganesh Moorthy, I, Rajeswari, R, Harikrishnan, H. 2011. "Utilization of waste ripe Banana, and peels for bioethanol production using Saccharomyces cerevisiae". Journal of Bioscience Research, 2(2): 67-71.

[13] Koul, V.K, Jain, M.P , Koul, S, Sharma, V.K , Tikoo, C.L, Jain,S.M. 2002. "Spray drying of beet root juice using different carriers". Indian Journal of Chemical Technology 9(5): 442-445.

[14]Roy, K, Gullapalli, S, Chaudhuri, U.R, Chakraborty, R. 2004. "The use of a natural colorant based on betalain in the manufacture of sweet products in India”. Internationbal Journal of Food Science and Technology, 39(10): 1087-1091.

[15] Kim, M.Y, Kim, E.J, Kim, Y.N, Choi, C, Lee, B.H. 2012. "Comparison of the chemical compositions and nutritive values of various pumpkin (Cucurbitaceae) species and parts". Nutrition. Research and Practice 6(1):21-27.

[16] Glew, R.H, Glew, R.S, Chuang, L.T, Huang,Y.S, Millson, M, Constans, D, Vanderjagt, D.J. 2006. “ Amino acid, mineral and fatty acid content of pumpkin seeds (Cucurbitaspp) and Cyperus esculentus nuts in the Republic of Niger". Plant Foods for Human Nutrition 6151-6156.

[17] Akponah, E, Akpomie, O.O. 2011. Analysis of the suitability of yam, potato and cassava root peels for bioethanol production using Saccharomyces cerevisae. International Research Journal of Microbiology 2(10): 393-398.
[18] Jimoh, S.O, Ado, S.A, Ameh, J.B. 2008. "Simultaneous saccharification and fermentation of yam peel to ethanol by co-culture of Aspergillus niger and Saccharomyces cerevisiae." Best Journal 6:96-100.

[19] Yang, B, Wyman, C.E. 2008. "Pretreatment: the key to unlocking low cost cellulosic ethanol". Biofuels, Bioproducts and Biorefining, 2: 26-40.

[20] Alvira, P, Tomas-Pejo, E, Ballesteros, M, Negro, M.J. 2010. Pretreatment technologies for an efficient bioethanol production process based on enzymatic hydrolysis, A review. Bioresource Technology, 101: 4851-4861.

[21] Kumar, P, Barrett DM, Delwiche MJ, Stroeve, P. 2009. "Methods for pretreatment of lignocellulosic biomass for efficient hydrolysis and biofuel production". Industrial Engineering Chemistry, Research, 48: 3713-3729. doi: 10.1021/ie801542g.

[22] Li, C, Knierim, B, Manisseri, C, Arora, R, Scheller, H.V Auer, M, Vogel, K.P, Simmons, B.A, Singh, S .2010. "Comparison of dilute acid and ionic liquid pretreatment of switchgrass: Biomass recalcitrance, delignification and enzymatic saccharification. Bioresource Technology, 101: 4900-4906.

[23] Sun, Y, Cheng, J. 2002. "Hydrolysis of lignocellulosic materials for ethanol production, a review". Bioresource Technology, 83: 1-11.

[24] Kaa,r W.E, Holtzapple, M.T. 2000. "Using lime pretreatment to facilitate the enzymic hydrolysis of corn stover". Biomass and Bioenergy, 18: 189-199.

[25] Saha, B.C, Cotta, M.A. 2008. "Lime pretreatment, enzymatic saccharification and fermentation of rice hulls to ethanol". Biomass and Bioenergy, 32: 971977.

[26] Xu, J, Chang, J.J, Shivappa, R.R.S, Burns, J.C. 2010. "Lime pretreatment of switchgrass at mild temperatures for ethanol production". Bioresource Technology, 101: 2900-2903.

[27] Carvalheiro, F, Duarte, L.C, Girio, F.M.2008. "Hemicellulose biorefineries: a review on biomass pretreatments". Journal of Science and Industrial Research, 67 : 849-864.

[28] Mithra, M.G, Padmaja, G. 2016. “Compositional profile and ultrastructure of steam and dilute sulfuric acid pretreated root and vegetable processing residues". Current Biotechnology, 7: 1-14.

[29] Mithra, M.G, Padmaja, G. 2017. "Lime pretreatment associated compositional and ultrastructural changes in selected root and vegetable processing residues". International Journal of Environmental Agricultural Biotechnology, 2(1): 306-318.

[30] Anon, 2014. "STARGENTM 002, Granular Starch Hydrolyzing Enzyme for Ethanol Production." 
Product Information published by Genencor International, a Division of Danisco., Danisco US Inc, accessed on 22 December

[31] Shanavas, S, Padmaja, G, Moorthy, S.N, Sajeev. M.S, Sheriff. J.T. 2011. "Process optimization for bioethanol productionfrom cassava starch using novel eco-friendly enzymes". Biomass and Bioenergy, 35:901-909.

[32] Moorthy, S,N, Padmaja, G, 2002. "A rapid titrimetric method for the determination of starch content of cassava tubers". Journal of Root Crops, 28: 30-37.

[33] Goering, H.D,Vansoest. P.J .1975. "Forage fiber analysis, Washington: USDA Agricultural Research Service.

[34] Updegroff, D.M. 1969. "Estimation of cellulose by anthrone reagent. Analytical Chemistry, 32: 420423.

[35] AOAC, 1995. Official Methods of Analysis. 16th ed. Washington, DC: Association of Official Agricultural Chemists,

[36] SAS, 2010. SAS Institute Inc, Cary, NC, USA.

[37] Chantawongsa, N, Kongkiattikajorn, J. 2013. "Pretreatment methods for banana peel as a substrate for the bioproduction of ethanol in SHF and SSF". International Journal of Computer, the Internet and Management, 21(2):15-19.

[38]Zheng, Y, Yu, C, Cheng, Y-S, Lee, C, Simmons, C.W, Dooley, T,M, Zhang, R, Jenkins, B.M, Vander Gheynst, J.S. 2012. "Integrating sugar beet pulp storage, hydrolysis and fermentation for fuel ethanol production". Applied Energy, 93:168-175.

[39] Himmel, M.E, Ding, S.Y, Johnson, D.K , Adney, W.S, Nimlo, M.R, Brady, J.W, Foust, T.D.2007. “ Biomass recalcitrance: Engineering plants and enzymes for biofuel production". Science 315: 804807.

[40] Wyman, C.E., Dale, B.E., Elander, R.T., Holtzapple, M., Ladisch, M.R., Lee, Y.Y., 2005. Coordinated development of leading biomass pretreatment technologies. Bioresoucer Technology. 96:19591966.

[41] Saha, B.C, Bothast, R.J. 1999. "Pretreatment and enzymatic saccharification of corn fiber". Applied Biochemistry and Biotechnology, 76: 65-77, doi: 0273-2289/99/76/0065/\$13.25.

[42] Chang, V,S, Holtzapple, M.T. 2000. Fundamental factors affecting enzymatic reactivity. Applied Biochemistry and Biotechnology. 84/86: 5-37.

[43] Hendriks, A.T.W.M, Zeeman, G. 2009. "Pretreatments to enhance the digestibility of lignocellulosic biomass". Bioresource Technology, 100:10-18.doi: 10.1016/j.biortech.2008.05.027.
[44] Divya Nair, M.P, Padmaja, G, Moorthy, S.N. 2011. "Biodegradation of cassava starch factory residue using a combination of cellulases, xylanases and hemicellulases".Biomass and Bioenergy. 35:12111218. doi: 10.1016/j.biombioe.2010.12.009.

[45] Pooja, N.S, Padmaja, G. 2015. "Enhancing the enzymatic saccharification of agricultural and processing residues of cassava through pretreatment techniques". Waste and Biomass Valorization, 6: 303-315.doi: 10.1007/s 12649-015-9345-8.

[46] Kim, S, Holtzapple, M.T. 2005. "Lime pretreatment and enzymatic hydrolysis of corn stover". Bioresource Technology, 96: 1994-2006.

[47] Chang, V.S, Nagvani, M, Kim, C.H, Holtzapple, M.T. 2001. "Oxidative lime pretreatment of highlignin biomass: poplar wood and newspaper". Applied Biochemistry and Biotechnology, 94: 1-28.

[48] Torre, M, Rodriguez, A.R, Saura-Calixto, F. 1992. "Study of the interactions of calcium ions with lignin, cellulose and pectin". Journal of Agriculture and Food Chemistry, 40:1762-1766.

[49] Sarkar, N, Ghosh, S.K, Bannerjee, S, Aikat, K. 2012. "Bioethanol production from agricultural wastes. An overview". Renewable Energy, 37: 1927. 